\title{
Photosynthesis, Carbon Flows and Growth of Oscillatoria agardhii Gomont in Environments with a Periodic Supply of Light
}

\author{
By ANTON F. POST, * JOHAN G. LOOGMAN AND LUUC R. MUR \\ Laboratorium voor Microbiologie, University of Amsterdam, Nieuwe Achtergracht 127, \\ 1018 WS Amsterdam, The Netherlands
}

(Received 3 September 1985; revised 21 March 1986)

\begin{abstract}
The cyanobacterium Oscillatoria agardhii was grown in continuous cultures with light periods of various duration at a constant irradiance. Growth at shorter light periods led to light-limited cultures. $P_{\max }$ was the only photosynthetic parameter that reflected increasing pigment contents at shorter light periods; $\alpha$ and $q_{\mathrm{O}}$, were maximal with light periods of $8 \mathrm{~h}$ and less. The dynamics of the carbohydrate pool with light/dark cycles are described in a concept of three maxima: a maximum accumulation rate, a maximum content and a maximum consumption rate. With shorter light periods the growth yield on carbon increased as did yield values for dark growth on carbohydrate. Rates of protein synthesis were equal in the light and dark for light periods $>8 \mathrm{~h}$; with shorter light periods the rates of protein synthesis in the dark showed a severe drop. From the response of $O$. agardhii to changes in light/dark cycle we distinguished four ranges in which regulation of growth differed. The central role of the photosynthetic apparatus in the different responses to changes in either irradiance or light period is stressed.
\end{abstract}

\section{INTRODUCTION}

Fluctuations in nutrient and energy flows are common in the natural environment of most micro-organisms. Planktonic cyanobacteria are subjected both to gradual changes in light intensity and to abrupt light/dark cycles, especially when light is the growth-limiting factor (Van Liere \& Mur, 1980; Foy \& Gibson, 1982). The underwater light gradient is determined by the incident irradiance and the absorption of light quanta by dissolved compounds and phytoplankton pigments. An increase in phytoplankton pigments causes a steeper attenuation of light, which favours the growth of cyanobacteria (Mur et al., 1977). The latter was explained by the low energy requirement for maintenance (Van Liere \& Mur, 1979) and the optimization of light harvesting and photosynthesis (Post et al., 1985a). In addition phytoplankton experience dark periods brought about by the daily light/dark (L/D) cycle and by vertical mixing. Especially in the case of cyanobacterial blooms the light attenuation shows such a steep gradient that the depth of mixing $\left(z_{\mathrm{m}}\right)$ exceeds the euphotic zone $\left(z_{\mathrm{eu}}\right)$ (Van Liere \& Mur, 1980). Low $z_{\text {eu }} / z_{\mathrm{m}}$ ratios cause short L/D cycles superimposed on the daily cycle (Loogman et al., 1980) and therefore many planktonic cyanobacteria receive a periodic irradiance gradient affecting their photosynthetic performance.

In cyanobacteria photosynthetic carbon fixation leads to a flow of carbon either to the tricarboxylic acid cycle or to glycogen (Smith, 1982). Glycogen is metabolized via the oxidative pentose phosphate cycle (see Smith, 1982), thus allowing for continued growth in the dark (Foy

Abbreviations: L/D cycle, light/dark cycle with total length of $24 \mathrm{~h} ; z_{\text {eu }}$, depth of euphotic zone (m); $z_{\mathrm{m}}$, depth of mixing $(\mathrm{m}) ; \alpha$, photosynthetic light utilization efficiency of cells $\left[\mu \mathrm{g} \mathrm{O}(\mathrm{mg} \mathrm{dry} \mathrm{wt})^{-1} \mathrm{~h}^{-1} \mathrm{~W}^{-1} \mathrm{~m}^{2}\right] ; P_{\max }$, photosynthetic capacity $\left[\mu \mathrm{g} \mathrm{O}_{2}(\mathrm{mg} \text { dry } w)^{-1} \mathrm{~h}^{-1}\right] ; q_{\mathrm{O}}$, rate of photosynthesis at culture irradiance level $\left.\left[\mu \mathrm{g} \mathrm{O}_{2} \text { (mg dry wt) }\right)^{-1} \mathrm{~h}^{-1}\right] ; I_{\mathrm{g}}$, culture irradiance level; $Y_{\mathrm{C}}$, yield coefficient for growth on photosynthetically fixed carbon [ $\mathrm{mg} \mathrm{C}$ in dry wt (mg C fixed $)^{-1}$ ]; $Y_{\mathrm{CH}_{2} \mathrm{O}}$, yield coefficient for growth in the dark on stored carbohydrates [mg dry wt (mg carbohydrate) ${ }^{-1}$. 
et al., 1976; Van Liere et al., 1979; Post et al., 1985b). At growth-limiting irradiances the rate of carbon fixation depends on the light-harvesting capacity of the cells, and the growth vs irradiance curve can be well described by the Monod equation for nutrient-limited growth (Post et al., 1985a). Adaptation to irradiance shows similar patterns of change in pigments, photosynthesis and growth rates when cells are grown with either a short L/D cycle (Foy, 1983), a long L/D cycle (Post et al., 1985a), or with continuous light (Van Liere \& Mur, 1980). When the period of illumination is decreased, keeping irradiance constant, the photosynthetic potential increases to drive an accelerated rate of carbon fixation in the light (Loogman, 1982; Post et al., $1985 b$ ); combined with an increased growth yield on carbon and a high dark growth yield on carbohydrates this can in part offset the loss of light supply (Post et al., 1985b). In this paper we report a study of the regulation of photosynthesis, carbon flows and growth of Oscillatoria agardhii Gomont in L/D cycles, with special emphasis on the carbohydrate pool that serves as storage of reserve polymers.

\section{METHODS}

Organism and growth. Oscillatoria agardhii Gomont was cultured in chemostats (2 l) in mineral medium (Van Liere \& Mur, 1978). The cultivation method was essentially that of the turbidostat (Loogman et al., 1980).

Determinations. Culture dry weight was determined by weighing washed and lyophilized pellets in cone-ended centrifuge tubes. Carbohydrates were determined on fivefold concentrated samples after washing with distilled water, using anthrone reagent in $96 \%(\mathrm{w} / \mathrm{v}) \mathrm{H}_{2} \mathrm{SO}_{4}$ and a D-glucose standard (Herbert et al., 1971). Proteins were determined on sonicated samples after washing and concentrating fivefold, using the Folin-Ciocalteu reagent and a bovine serum albumin standard (Sigma), according to Herbert et al. (1971).

After extraction in boiling methanol, chlorophyll $a$ concentration was calculated from absorption spectra obtained using a Pye Unicam SP8-100 spectrophotometer (Talling \& Driver, 1961). C-phycocyanin was extracted by sonicating samples in $0.01 \mathrm{M}$-sodium phosphate buffer $(\mathrm{pH} 7.0)$ followed by centrifugation at $12000 \mathrm{~g}$ then at $81000 \mathrm{~g}$ to remove all membrane fragments (Tandeau de Marsac, 1977). C-phycocyanin concentrations were calculated using the equations of Bennet \& Bogorad (1973) from the absorbances at 628 and $652 \mathrm{~nm}$.

Photosynthetic $\mathrm{O}_{2}$ evolution was determined over a wide range of irradiances as described by Zevenboom et al. (1983). Respiration was determined before illumination of the sample. Gross photosynthetic activities were calculated by correcting for the rate of respiration. The initial slopes $(\alpha)$ of the photosynthesis-light curves were determined by linear regression analysis of $\mathrm{O}_{2}$ production rates at low irradiances $\left(<10 \mathrm{~W} \mathrm{~m}^{-2}\right)$ and represent the light utilization efficiency of the cells. $P_{\max }$ and $q_{\mathrm{O}}$, were determined by averaging $\mathrm{O}_{2}$ production rates at saturating and culture irradiance, respectively. Yield coefficients were calculated as described by Post et al. (1985b), using a photosynthetic quotient of $0.92 \mathrm{~mol} \mathrm{C}$ fixed per mol $\mathrm{O}_{2}$ evolved (A. F. Post \& K. Koelemay, unpublished results). All data are the means of at least three replicates.

\section{RESULTS}

Shortening the length of the light period while keeping the irradiance constant led to lightlimited cultures of $O$. agardhii as shown by the growth rates $(\mu)$ (Fig. $1 a)$. The growth rates were determined as period-averaged growth rates, i.e. with $24 \mathrm{~h}$ intervals, and expressed on an hourly basis. Continuous irradiance of $28 \mathrm{~W} \mathrm{~m}^{-2}$ allowed $O$. agardhii to grow at the maximum growth rate $\left(\mu_{\max }\right)$. The periodic supply of irradiance in $24 \mathrm{~h} \mathrm{~L} / \mathrm{D}$ cycles allowed for $\mu_{\max }$ when the light periods were longer than $16 \mathrm{~h}$. At shorter light periods growth rates declined almost linearly. Extrapolation of the curve to the maintenance constant, $\mu_{\mathrm{e}}\left(-0.001 \mathrm{~h}^{-1}\right.$ after Van Liere \& Mur, 1979), yielded an intercept on the $x$-axis at $15 \mathrm{~min}$, the minimal light period needed to maintain culture viability. Post et al. (1985a) showed that $\mu$ may be described as a function of irradiance (I) at each growth temperature by the Monod equation:

$$
\mu=\mu_{\max } \times\left[I /\left(K_{I}+I\right)\right]
$$

in which $K_{I}$ is the half-saturation constant. Applying the Monod equation to the periodaveraged $\mu$ as a function of light period length $(L)$ converts the equation to:

$$
\mu_{L / D}=\mu_{\max } \times\left[L /\left(K_{L}+L\right)\right]
$$

in which $K_{L}$ denotes the light period needed to attain $0.5 \mu_{\max }$. A fit of growth rate data to equation (2) yielded a calculated $\mu_{\max }$ of $0.043 \pm 0.004 \mathrm{~h}^{-1}$ and a $K_{L}$ of $5.6 \pm 0.54 \mathrm{~h}$ with a 


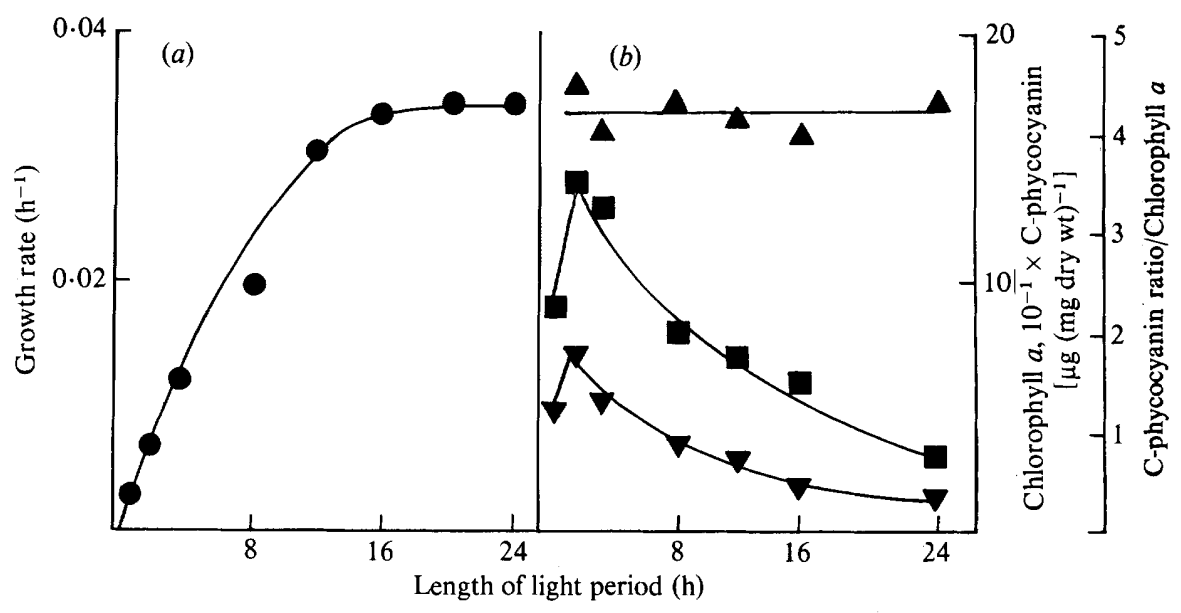

Fig. $1(a, b)$. Variation in growth rate $(\boldsymbol{O})$, chlorophyll $a(\boldsymbol{\square})$ and $\mathrm{C}$-phycocyanin $(\boldsymbol{\nabla})$ contents, and pigment ratio $(\Delta)$ for $O$. agardhii grown at a constant irradiance of $28 \mathrm{~W} \mathrm{~m}^{-2}$ as a function of length of the light period.

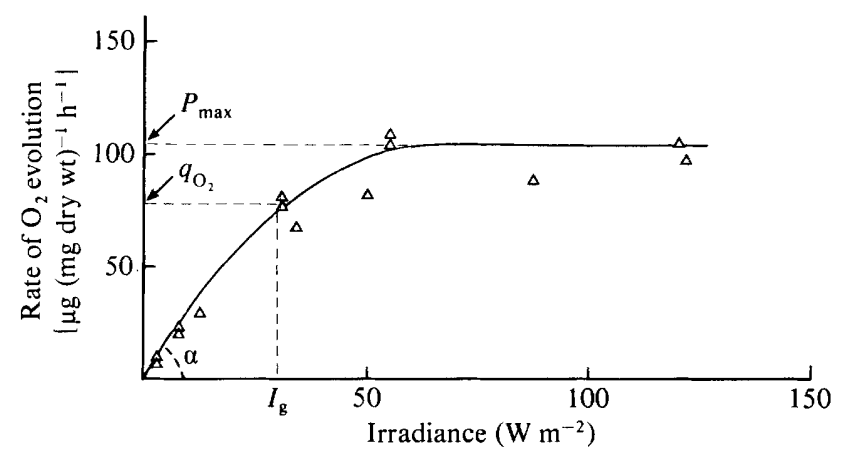

Fig. 2. Photosynthetic $\mathrm{O}_{2}$ evolution as a function of irradiance for $O$. agardhii determined on samples taken from a culture growing at $28 \mathrm{~W} \mathrm{~m}^{-2}$ and a $12 / 12 \mathrm{~h} \mathrm{~L} / \mathrm{D}$ cycle.

reasonable correlation $\left(r^{2}=0.97 ; n=8\right)$. In order to compare $K_{I}$ and $K_{L}$ both have to be normalized to the daily light dose $(I \times L)$. $K_{I}^{24}$ was $8.64 \times 10^{4} \mathrm{~J} \mathrm{~m}^{-2}$ (Post et al., 1985a) and $K_{L}^{24}$ yielded a value of $5.64 \times 10^{5} \mathrm{~J} \mathrm{~m}^{-2}$. Since $\mu_{\max }$ was constant in both experiments we conclude that the effect brought about by changes in irradiance was much greater than those brought about by changes in light period.

The contents of chlorophyll $a$ and C-phycocyanin increased at shorter light periods (Fig. 1b) as they did on adaptation to limiting irradiance. For both pigments, maximum contents were found at a $2 / 22 \mathrm{~h} \mathrm{~L} / \mathrm{D}$ cycle, and at a $1 / 23 \mathrm{~h} \mathrm{~L} / \mathrm{D}$ cycle a reduction in pigment contents was observed. The ratio of C-phycocyanin to chlorophyll $a$ was not affected by varying the length of the light period. The increase in pigment contents at shorter light periods correlated with an increase in the photosynthetic potential of $O$. agardhii. A typical curve of the photosynthesisirradiance relationship is given in Fig. 2. Photosynthetic activities increased with irradiance until a maximum was reached that was maintained over a range of irradiances. Photosynthetic activities at culture irradiance $\left(I_{g}\right)$ never occurred at the maximal rate. Fig. 3 shows the photosynthetic parameters of $O$. agardhii as determined at the start of the light period. The photosynthetic capacity $\left(P_{\max }\right)$ followed the changes in pigments and increased with shorter light periods, with a maximum at $2 / 22 \mathrm{~h} \mathrm{~L} / \mathrm{D}$. The light utilization efficiency of the cells $(\alpha)$ did not reflect the changes in pigment contents but increased with shorter light periods until a 


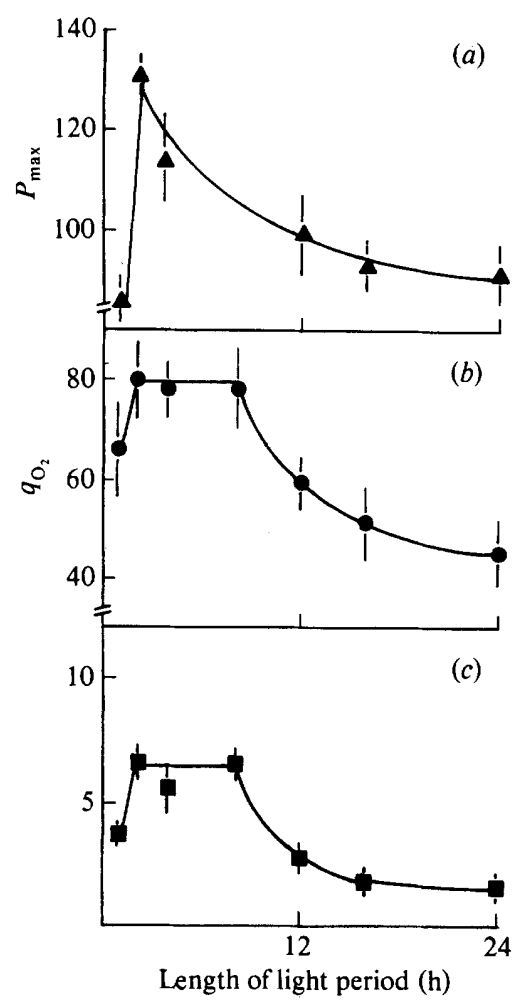

Fig. 3. Changes in the photosynthetic parameters $P_{\max }\left[\mu \mathrm{g} \mathrm{O} \mathrm{O}_{2}(\mathrm{mg} \text { dry wt })^{-1} \mathrm{~h}^{-1}\right](a), q_{\mathrm{O}}\left[\mu \mathrm{g} \mathrm{O} \mathrm{O}_{2}\right.$ (mg dry wt $\left.)^{-1} \mathrm{~h}^{-1}\right](b)$ and $\left.\alpha[\mu \mathrm{g} \mathrm{O} \text { (mg dry wt) })^{-1} \mathrm{~h}^{-1} \mathrm{~W}^{-1} \mathrm{~m}^{2}\right](c)$ as a function of the length of the light period for $O$. agardhii grown at $28 \mathrm{~W} \mathrm{~m}^{-2}$. Bars indicate standard deviation.

maximum was reached at $8 / 16 \mathrm{~h} \mathrm{~L} / \mathrm{D}$ to $2 / 22 \mathrm{~h} \mathrm{~L} / \mathrm{D}$ cycles. The net effect for the cells was that $\mathrm{O}_{2}$ production at culture irradiance $\left(q_{\mathrm{O}_{2}}\right)$ was also maximal at $8 / 16 \mathrm{~h} \mathrm{~L} / \mathrm{D}$ to $2 / 22 \mathrm{~h} \mathrm{~L} / \mathrm{D}$ cycles. With the longer light periods $q_{\mathrm{O}_{2}}$ decreased and was minimal at light periods longer than $16 \mathrm{~h}$. At a $1 / 23 \mathrm{~L} / \mathrm{D}$ cycle photosynthesis was low due to the low pigment contents. At the end of the $1 \mathrm{~h}$ light period pigments and photosynthesis were at the same maximal level as with the $2 / 22 \mathrm{~h} \mathrm{~L} / \mathrm{D}$ cycle.

Increasing photosynthetic activities serve to sustain the synthesis of cell components and for accumulation of carbohydrates as the sole carbon source for growth during the dark (Post et al., $1985 b$ ). Carbohydrates accumulated apparently linearly with time for $O$. agardhii grown with a 12/12 h L/D cycle (Fig. 4). The decline of carbohydrates in the dark was also linear with time and the minimum carbohydrate content was reached at the end of the dark period. The rate of carbohydrate accumulation, $32 \pm 2 \mu \mathrm{g}(\mathrm{mg} \text { dry wt })^{-1} \mathrm{~h}^{-1}\left(n=8 ; r^{2}=0.99\right)$ was similar to the rate of carbohydrate consumption, $29 \pm 1 \mu \mathrm{g}$ (mg dry wt) $)^{-1} \mathrm{~h}^{-1}$. The minimal carbohydrate content of the cells decreased from $350 \mu \mathrm{g}(\mathrm{mg} \text { dry wt) })^{-1}$ at $24 / 0 \mathrm{~h} \mathrm{~L} / \mathrm{D}$ to $107 \mu \mathrm{g}$ (mg dry wt) $)^{-1}$ at $8 / 16 \mathrm{~h} \mathrm{~L} / \mathrm{D}$ and increased again to $184 \mu \mathrm{g}(\mathrm{mg} \text { dry wt })^{-1}$ at $1 / 23 \mathrm{~h} \mathrm{~L} / \mathrm{D}$. The maximum carbohydrate content was $530 \pm 40 \mu \mathrm{g}$ (mg dry wt) ${ }^{-1}$ and was reached with the $8 / 16,12 / 12$ and $16 / 8 \mathrm{~h} \mathrm{~L} / \mathrm{D}$ cycles. For all L/D cycles carbohydrates increased linearly during the light period and the rate of accumulation increased with the shorter $L / D$ cycles. Fig. 5 shows the carbohydrate accumulation rates in relation to light period length. Accumulation rates were maximal at $48 \pm 3 \mu \mathrm{g}(\mathrm{mg} \text { dry wt) })^{-1} \mathrm{~h}^{-1}$ for the short $\mathrm{L} / \mathrm{D}$ cycles. With longer light periods $(>8 \mathrm{~h})$ the rate decreased linearly, with an intercept on the $x$-axis at $22 \mathrm{~h}$. For the culture in continuous light the accumulation rate was zero (by definition). Apparently a dark period of at least $2 \mathrm{~h}$ was needed to trigger the accumulation of carbohydrate reserve polymers in order to offset the periodic supply of light energy. 


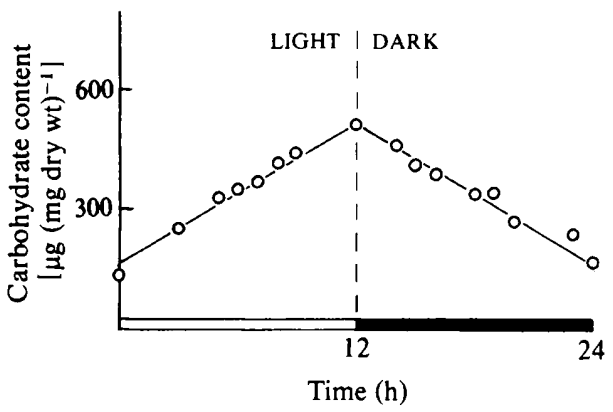

Fig. 4

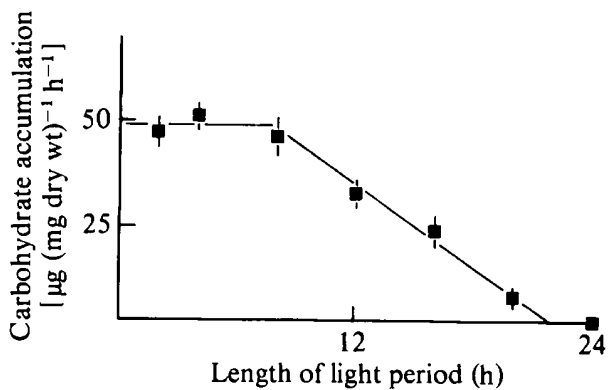

Fig. 5

Fig. 4. Pattern of carbohydrate accumulation and consumption during a $12 / 12 \mathrm{~h} \mathrm{L/D}$ cycle for $\boldsymbol{O}$. agardhii grown at $28 \mathrm{~W} \mathrm{~m}^{-2}$.

Fig. 5. Rate of carbohydrate accumulation as a function of length of the light period for $O$. agardhii grown at $28 \mathrm{~W} \mathrm{~m}^{-2}$. Bars indicate standard deviation.

Table 1. Growth rates, protein synthesis and yield coefficients for $O$. agardhii grown with various $L / D$ cycles

\begin{tabular}{cccccr} 
L/D & \multicolumn{2}{c}{$\begin{array}{c}\text { Rate of protein } \\
\text { synthesis }\left(\mathrm{h}^{-1}\right)\end{array}$} & $\overbrace{\text { Light }}^{\mu}$ & Dark & $\overbrace{Y_{\mathrm{CH}_{2} \mathrm{O}}}^{\text {Yield coefficients }}$ \\
$1 / 23$ & 0.003 & ND & ND & 0.99 & $Y_{\mathrm{C}}$ \\
$2 / 22$ & 0.007 & 0.021 & 0.007 & 0.91 & 0.98 \\
$4 / 20$ & 0.012 & 0.023 & 0.010 & 0.85 & 0.97 \\
$8 / 16$ & 0.018 & 0.027 & 0.014 & 0.71 & 0.78 \\
$12 / 12$ & 0.029 & 0.028 & 0.031 & 0.50 & 0.88 \\
$16 / 8$ & 0.033 & 0.033 & 0.033 & 0.40 & 0.84 \\
$24 / 0$ & 0.034 & 0.034 & - & - & $0.70^{*}$
\end{tabular}

ND, Not determined; -, not measurable in continuous light.

* After Post et al. (1985b).

Proteins were synthesized during light and dark periods as shown in Table 1. For the L/D cycles with a light period of $12 \mathrm{~h}$ or more the rates of synthesis were equal. With shorter light periods the rates of protein synthesis in the light exceeded those in the dark. Growth in the dark occurred at the expense of carbohydrates. In addition to an increase in carbon fixation per light hour with shorter L/D cycles, growth was also determined by the efficiency factors of carbon conversion to biomass. In this study we distinguished two yield coefficients: $Y_{\mathrm{CH}_{2} \mathrm{O}}$, the yield coefficient for growth in the dark on carbohydrate ( $\mathrm{g}$ biomass per $\mathrm{g}$ carbohydrate) and $Y_{\mathrm{C}}$, the overall efficiency of carbon fixed in the light and converted into biomass during the $\mathrm{L} / \mathrm{D}$ cycle. The average carbon content of $O$. agardhii was $38 \pm 3 \%$ of dry weight for all $\mathrm{L} / \mathrm{D}$ cycles. Since $Y_{\mathrm{C}}$ was partly determined by $Y_{\mathrm{CH}_{2} \mathrm{O}}, Y_{\mathrm{C}}$ also increased with shorter light periods and reached almost unity with L/D cycles of $4 / 20 \mathrm{~h}$ and shorter (Table 1). $Y_{\mathrm{C}}$ did not decline as rapidly as $Y_{\mathrm{CH}_{2} \mathrm{O}}$, indicating that carbon losses were very low in the light, while the dark yield $Y_{\mathrm{CH}_{2} \mathrm{O}}$ became a less important factor with the longer light periods.

\section{DISCUSSION}

The periodic supply of irradiance led to light-limited cultures of $O$. agardhii. The growth response to shorter L/D cycles was similar to that found for low growth irradiances (Foy et al., 1976; Foy, 1983; Post et al., 1985a). Adaptation to shorter light periods occurred by (a) increased photosynthesis rates driving high rates of synthesis of proteins and carbohydrates, and (b) increased growth yields on carbon based on increased dark growth yields on carbohydrates. 
Growth rates fitted to the length of the light period with the Monod equation as was found for irradiance (Post et al., 1985a). However, $K_{L}^{24}$ exceeded $K_{I}^{24}$ by a factor of 6.5 . From this it follows that adaptation to irradiance is far more effective than adaptation to shorter light periods and therefore light-limited growth cannot be described in the concept of a daily light dose as suggested for other cyanobacteria (Gibson \& Foy, 1983; Zevenboom \& Mur, 1984). Pigment contents of $O$. agardhii increased at short light periods and at low irradiances, but the pigment ratio was essentially constant for all light periods. This is in contrast with the increasing $\mathrm{C}$ phycocyanin/chlorophyll $a$ ratios for $O$. agardhii and $O$. redekei with lower irradiance values (Post et al., 1985a; Foy \& Gibson, 1982), but similar to the constant ratio in Microcystis aeruginosa with variation in both irradiance and length of light period (Zevenboom \& Mur, 1984). At light periods shorter than $8 \mathrm{~h}$ pigment increase was no longer reflected in increased rates of photosynthesis. Since $\mathrm{O}_{2}$ evolution is in essence photosystem II activity one may expect no increase in photosynthetic activity at shorter light periods when pigment increase only contributes to photosystem I activity. Kawamura et al. (1979) showed that in low light photosystem I pigments increase relative to photosystem II pigments. If true for $O$. agardhii this effect is more pronounced at short light periods than at low irradiances, where photosynthesis always reflects pigment contents.

Carbohydrate dynamics in $O$. agardhii show (1) a maximal accumulation rate at light periods of $<8 \mathrm{~h},(2)$ a maximal carbohydrate content at light periods of 8-16 h, and (3) a maximal dark consumption rate with light periods of $>16 \mathrm{~h}$. These data largely agree with those for $O$. agardhii and $O$. redekei grown in batch cultures (Foy \& Smith, 1980; Foy \& Gibson, 1982; Foy, 1983). Foy \& Smith (1980) suggested that glycogen storage resulted from an unavailability of nitrogen in the light period. From the high rates of protein synthesis in the light $\left(>0.6 \mu_{\max }\right)$ for all $\mathrm{L} / \mathrm{D}$ cycles, we conclude that nitrate uptake in the light is sufficient to meet all growth demands. We suggest that regulation of carbohydrate storage results from the regulation of photosynthetic activities. With shorter light periods the rates of synthesis of proteins in the dark are substantially lowered, allowing for an increased pigment synthesis, enhanced photosynthetic carbon fixation and thereby the flow of carbon to carbohydrate storage. During the following dark period pigment synthesis is depressed due to increased rates of protein synthesis at the expense of carbohydrates. Since 2-oxoglutarate and glutamate are intermediates of both pigment and protein synthesis, it has been suggested that pigment synthesis results from competition for these intermediates controlled by photophosphorylation (Falkowski, 1980). Noting that long dark periods will have similar effects on the energy charge as low irradiances we suggest that pigment synthesis is controlled in a similar way with L/D cycles. Increasing yields for growth on carbohydrates must be explained by lower respiratory losses of carbon at lower growth rates. This can be attained by, for example, increasing $\mathrm{P} / \mathrm{O}$ ratios (Nitschmann \& Peschek, 1982; Pelroy \& Bassham, 1973) so that less NAD(P) $\mathrm{H}_{2}$ is needed for respiratory ATP generation.

Growth yields on carbon with shorter $\mathrm{L} / \mathrm{D}$ cycles increased due to increasing $Y_{\mathrm{CH}_{2} \mathrm{O}}$ and a higher flow of carbon to protein synthesis. Post et al. $(1985 \mathrm{~b})$ showed that in $O$. agardhii grown at high light $\mu$ was constant over the $8 / 16 \mathrm{~h} \mathrm{~L} / \mathrm{D}$ cycle, in contrast to the heterotroph Klebsiella aerogenes NTCC 418 with a periodic supply of glucose (Leegwater, 1983). The markedly varying $\mu$ in the latter was attributed to the lack of glycogen storage, a conclusion which does not hold for $O$. agardhii with shorter light periods. Obviously, $\mu$ is tuned in a more subtle way to the periodic supply of nutrients and energy. We were able to distinguish four different ranges of growth with periodic supply of light energy. Firstly, a range $(24 / 0 \mathrm{~h} \mathrm{~L} / \mathrm{D}$ to $22 / 2 \mathrm{~h} \mathrm{~L} / \mathrm{D})$ in which $\mu$ is maximal and $L / D$ cycles do not effect any response. In the second range (16/8 h L/D to $22 / 2 \mathrm{~h} \mathrm{L/D)} \mu$ is still maximal as a result of adaptive response in pigments, photosynthesis and carbohydrate storage. The third range $(8 / 16 \mathrm{~h} \mathrm{~L} / \mathrm{D}$ to $16 / 8 \mathrm{~h} \mathrm{~L} / \mathrm{D})$ is defined by submaximal growth rates that do not fluctuate during the $L / D$ cycle. The adaptive responses are strongest in this range. The adaptive potential has been explored completely in the fourth range (light periods $<8 \mathrm{~h}$ ) and the storage of reserve polymers can no longer prevent a severe drop in $\mu$ during dark periods.

These responses form the basis for the dominance of $O$. agardhii in its natural environment. The advantage of adjustment of photosynthetic response to changes in either irradiance or light 
period is obvious, since both occur regularly. The changes in photosynthetic response are governed by light conditions and not strictly coupled to growth rate as suggested by Riegman $\boldsymbol{e t}$ al. (1985). Occurrence of blooms of $O$. agardhii has been related to low irradiances (Mur et al., 1977 ) and to low $z_{\mathrm{eu}} / z_{\mathrm{m}}$ ratios (Reynolds \& Walsby, 1975; Van Liere \& Mur, 1980). In constantly mixing water columns a $z_{\mathrm{eu}} / z_{\mathrm{m}}$ ratio of $0.2-0.4$ implies that phytoplankton are in the light for 20$40 \%$ of the daytime, corresponding to $2 \cdot 4-4.8 \mathrm{~h}$ if the average daytime is taken to be $12 \mathrm{~h}$. Loogman et al. (1980) showed that light periods of $4 \mathrm{~h}$ and less favour the growth of $O$. agardhii over Scenedesmus protuberans Fritsch, a green alga, which did not adapt to shorter light periods by increasing its photosynthetic performance (Post et al., 1985c). With the lower maintenance rate constant of $O$. agardhii, $-0.001 \mathrm{~h}^{-1}$ vs $-0.008 \mathrm{~h}^{-1}$ for $S$. protuberans (Van Liere \& Mur, 1979; Gons \& Mur, 1980), increased photosynthetic activities form the basis for higher growth rates at the given $z_{\text {eu }} / z_{\mathrm{m}}$ ratios. The control over photosynthetic activities seems to be founded in the regulation of carbon flows, so that the growth response of $O$. agardhii can be optimized for any combination of irradiance and light period.

This research project was in part enabled by a grant of the Delft Hydraulics Laboratory and the Department of Water Management, Deltadienst, Middelburg. We especially thank Jeannine Ebert for technical assistance.

\section{REFERENCES}

Bennet, A. \& Bogorad, L. (1973). Complementary chromatic adaption in a filamentous blue-green alga. Journal of Cell Biology 58, 419-435.

FALkowsKI, P. G. (1980). Light-shade adaptation in marine phytoplankton. In Primary Productivity in the Sea, pp. 99-119. Edited by P. G. Falkowski. New York: Plenum Press.

FoY, R. H. (1983). Interaction of temperature and light on the growth rates of two planktonic Oscillatoria species under a short photoperiod regime. British Phycological Journal 18, 267-273.

FoY, R. H. \& Gibson, C. E. (1982). Photosynthetic characteristics of planktonic blue-green algae: the response to twenty strains grown under high and low light. British Phycological Journal 17, 169-182.

FoY, R. H. \& SMITH, R. V. (1980). The role of carbohydrate accumulation in the growth of planktonic Oscillatoria species. British Phycological Journal 15, 139-150.

Foy, R. H., Gibson, C. E. \& SMITH, R. V. (1976). The influence of daylength, light intensity and temperature on the growth rates of planktonic blue-green algae. British Phycological Journal 11, 151-163.

Gibson, C. E. \& FoY, R. H. (1983). The photosynthesis and growth efficiency of a planktonic blue-green alga Oscillatoria redekei. British Phycological Journal 18, 39-45.

GoNs, H. J. \& MUR, L. R. (1980). Energy requirements for growth and maintenance of Scenedesmus protuberans Fritsch in light-limited continuous cultures. Archives of Microbiology 125, 9-17.

Herbert, D., Phipps, P. J. \& Strange, R. E. (1971). Chemical analysis of microbial cells. Methods in Microbiology 5B, 209-344.

Kawamura, M., Mimuro, M. \& Fujita, Y. (1979). Quantitative relationship between two reaction centers in the photosynthetic system of blue-green algae. Plant and Cell Physiology 20, 697-705.

LEEGWATER, M. P. M. (1983). Microbial reactivity: its relevance to growth in natural and artificial environments. PhD thesis, University of Amsterdam.

LOOGMAN, J. G. (1982). Influence of photoperiodicity on algal growth kinetics. PhD thesis, University of Amsterdam.

Loogman, J. G., Post, A. F. \& MuR, L. R. (1980). The influence of periodicity in light conditions, as determined by the trophic state of the water, on the growth of the green alga Scenedesmus protuberans and the cyanobacterium Oscillatoria agardhii. In Hypertrophic Ecosystems, pp. 79-82. Edited by J. Barica \& L. R. Mur. The Hague: Junk.

MUR, L. R., Gons, H. J. \& VAN Liere, L. (1977). Some experiments on the competition between green algae and blue-green bacteria in light-limited environments. FEMS Microbiology Letters 1, 335-338.

NitschmanN, W. H. \& PescheK, G. A. (1982). Oxidative phosphorylation in intact cyanobacteria. FEBS Letters 139, 77-80.

Pelroy, R. A. \& Bassham, J. A. (1973). Efficiency of energy conversion by aerobic glucose metabolism in Aphanocapsa 6714. Journal of Bacteriology 115, 937942.

Post, A. F., De Wit, R. \& MuR, L. R. (1985a). Interactions between temperature and light intensity on growth and photosynthesis of the cyanobacterium Oscillatoria agardhii. Journal of Plankton Research 7, 487-495.

Post, A. F., Loogman, J. G. \& Mur, L. R. (1985b). Regulation of growth and photosynthesis by Oscillatoria agardhii grown with a light/dark cycle. FEMS Microbiology Ecology 31, 97-102.

Post, A. F., Eijgenraam, F. \& MUR, L. R. (1985c). Influence of light period length on photosynthesis and synchronous growth of the green alga Scenedesmus protuberans. British Phycological Journal 20, 391397.

ReYNOLDS, C. S. \& WalsBy, A. E. (1975). Waterblooms. Biological Reviews 50, 437-481.

Riegman, R., Rutgers, M. \& Mur, L. R. (1985). Effects of photoperiodicity and light irradiance on phosphate-limited Oscillatoria agardhii in chemostat cultures. I. Photosynthesis and carbohydrate storage. Archives of Microbiology 142, 66-71.

SmITH, A. J. (1982). Modes of cyanobacterial carbon 
metabolism. In The Biology of the Cyanobacteria, pp. 47-86. Edited by N. G. Carr \& B. A. Whitton. Oxford: Blackwell.

Talling, J. F. \& Driver, D. (1961). Some problems in the estimation of chlorophyll $a$ in phytoplankton. In Proceedings of the Conference on Primary Productivity Measurement, Marine and Fresh Water, pp. 142-146. Edited by M.S. Doty. Washington, DC: US Atomic Energy Commission.

TANDEAU de Marsac, N. (1977). Occurrence and nature of chromatic adaptation in cyanobacteria. Journal of Bacteriology 130, 82-91.

VAN LIERE, L. \& MUR, L. R. (1978). Light-limited cultures of the blue-green alga Oscillatoria agardhii. Mitteilungen der internationale Vereinigung für theoretische und angewandte Limnologie 21, 158-167.

VAN LIERE, L. \& MUR, L. R. (1979). Growth kinetics of Oscillatoria agardhii Gomont in continuous culture, limited in its growth by the light energy supply. Journal of General Microbiology 115, 153-160.
VAN LIERE, L. \& MUR, L. R. (1980). Occurrence of Oscillatoria agardhii and some related species, a survey. In Hypertrophic Ecosystems, pp. 67-77. Edited by J. Barica \& L. R. Mur. The Hague: Junk. VAN Liere, L., MUR, L. R., Gibson, C. E. \& Herdman, M. (1979). Growth and physiology of Oscillatoria agardhii Gomont cultivated in continuous culture with a light-dark cycle. Archives of Microbiology 123, 315-318.

ZeVenBOOM, W. \& MUR, L. R. (1984). Growth and photosynthetic response of the cyanobacterium Microcystis aeruginosa in relation to photoperiodicity and irradiance. Archives of Microbiology 139, 232239.

Zevenboom, W., Post, A. F., Van Hes, U. M. \& Mur, L. R. (1983). A new incubator for measuring photosynthetic activity of phototrophic organisms, using the amperometric oxygen method. Limnology and Oceanography 28, 787-791. 